\title{
Upwelling intensity and wave exposure determine recruitment of intertidal mussels and barnacles in the southern Benguela upwelling region
}

\author{
Maya C. Pfaff ${ }^{1, *}$, George M. Branch ${ }^{1}$, Evie A. Wieters ${ }^{1,2,3}$, Ruth A. Branch ${ }^{4}$, \\ Bernardo R. Broitman ${ }^{2,5}$ \\ ${ }^{1}$ Marine Biology Research Center, Ma-RE Institute, Zoology Department, University of Cape Town, Rondebosch 7701, \\ South Africa \\ ${ }^{2}$ Estación Costera de Investigaciones Marinas and Center for Advanced Studies in Ecology and Biodiversity (CASEB), \\ Pontificia Universidad Católica de Chile, Santiago, Chile \\ ${ }^{3}$ Department of Zoology and Entomology, Rhodes University, Grahamstown 6140, South Africa \\ ${ }^{4}$ Applied Physics Laboratory, University of Washington, Seattle, Washington 98105-6698, USA \\ ${ }^{5}$ Centro de Estudios Avanzados en Zonas Áridas (CEAZA), Facultad de Ciencias del Mar, Universidad Católica del Norte, \\ 1781421 Coquimbo, Chile
}

\begin{abstract}
Marine larval dispersal and recruitment dynamics are fundamentally linked with nearshore circulation. In coastal upwelling systems, shoreline topography induces predictable circulation patterns, spanning a range of spatial and temporal scales. Based on a 5 yr time series of monthly recruitment of intertidal mussels and barnacles at 8 sites along $400 \mathrm{~km}$ of the southern Benguela upwelling region, which extends around the Cape of Good Hope, South Africa, we addressed the hypothesis that recruitment will exhibit spatial and temporal patterns reflecting the influence of topography and season on upwelling. Both taxa showed strongly seasonal recruitment peaks: mussels during the summer upwelling season and barnacles during spring. Spatially, mussels and barnacles differed in their regional-scale recruitment trends: recruitment of mussels increased northwards while that of barnacles peaked in the south. However, their mesoscale recruitment patterns were alike, with lower recruitment rates at headland upwelling centers than in adjacent bays. On a smaller scale of hundreds of meters, wave exposure had a positive effect on the recruitment of mussels and (to a lesser extent) barnacles. Spatial patterns were remarkably persistent over time and, for barnacles, strongly negatively correlated with upwelling, as quantified by a site-specific coastal upwelling index. The effect of temporal upwelling dynamics on recruitment was site dependent: mussel recruitment was strongly and positively correlated with upwelling at all sites, while barnacle recruitment showed a weak and spatially inconsistent link to upwelling fluctuations. The persistence of the spatial structure of recruitment and its coherence between unrelated taxa emphasizes the role of shoreline topography, thereby increasing our capacity to include regional-scale processes in the management and conservation of coastal ecosystems.
\end{abstract}

KEY WORDS: Recruitment $\cdot$ Invertebrate larvae $\cdot$ Intertidal $\cdot$ Nearshore $\cdot$ Oceanography $\cdot$ South Africa $\cdot$ Headland bay $\cdot$ Invasive

Resale or republication not permitted without written consent of the publisher

\section{INTRODUCTION}

For most benthic marine organisms, fluctuations in the arrival of broadly dispersing pelagic larvae and their subsequent recruitment to adult populations are among the most important factors driving metapopulation dynamics, and have a powerful effect on species interactions and community regulation (Connell 1985, Menge \& Sutherland 1987, Roughgarden et al. 1988, Menge et al. 1997). Because dispersal and supply of 
larvae to suitable settlement habitats are highly dependent upon coastal water movements during larval development, large variability in recruitment can occur over various spatial and temporal scales and may be greatly influenced by the effects of topography and season on oceanographic processes (Menge et al. 1997, Botsford 2001, Navarrete et al. 2005).

In eastern-boundary upwelling ecosystems, onshore transport of larvae from coastal populations is associated with cross-shelf currents linked with different phases of the upwelling cycle. As strong equatorward winds displace surface waters offshore, bottom waters are forced upwards along the shelf and upwell near the coast, potentially carrying particles and larvae suspended in deep layers of the water column with them (Shanks et al. 2000, Garland et al. 2002). When equatorward winds relax or reverse, the process inverts, transporting surface waters and entrained larvae shoreward, while coastal waters are downwelled, being displaced down and offshore (Farrell et al. 1991, Wing et al. 1995b). However, the mechanisms of larval transport driven by upwelling circulation may be more complex, involving larval behaviors that counteract their cross-shore transport (Morgan et al. 2009, Shanks \& Shearman 2009) and local-scale processes that may interact with the mesoscale circulation (McCulloch \& Shanks 2003, Rilov et al. 2008). The intensity and frequency of upwelling-downwelling events vary with season, region and coastal topography, affecting recruitment dynamics at various scales. Abrupt discontinuities in recruitment rates of intertidal mussels and barnacles have been associated with transitions in upwelling intensity and frequency over regional scales spanning hundreds to thousands of kilometers (Harris et al. 1998, Menge et al. 1999, Connolly et al. 2001, Broitman et al. 2005, 2008, Navarrete et al. 2005). Within a region, the interaction of wind-driven equatorward flow with coastline and bottom topography generates intense upwelling plumes in the wake of major headlands, while downstream bays typically experience diminished upwelling, cross-shore advection and retention of water (Graham \& Largier 1997, Gan \& Allen 2002). Such topographically locked patterns are reflected in mesoscale (10 to $100 \mathrm{~km}$ ) recruitment patterns of sea urchins and crabs in the California and Humboldt upwelling regions off the west coasts of North and South America, respectively, showing recruitment rates that are lower at headlands than those in bays (e.g. Ebert \& Russell 1988, Wing et al. 1995a, Botsford 2001, Palma et al. 2006). Intertidal mussel and barnacle recruitment patterns in the Humboldt region correspond only weakly to upwelling variability (Navarrete et al. 2005), but their persistence over time indicates that they may also be topographically locked (Lagos et al. 2008, Navarrete et al. 2008). On smaller spatial scales (tens to hundreds of meters), small promontories create gradients of wave exposure affecting recruitment rates (Hunt \& Scheibling 1996), which may contribute to striking differences among communities between wave-exposed and wave-protected habitats (Bustamante \& Branch 1996).

The southern Benguela upwelling region is unique in that it extends around the Cape of Good Hope, South Africa, which is a major barrier for larval transport and a well-known biogeographic break (Emanuel et al. 1992). Strong mesoscale discontinuities of upwelling are associated with a series of 3 major headlands forming upwelling centers, where cold water plumes emerge during pulses of equatorward winds in the austral summer (Jury 1988, Shannon \& Nelson 1996). Downstream of each upwelling center lies a major bay, where upwelled waters from the adjacent upwelling plumes are advected and retained by cyclonic eddies (Penven et al. 2000), commonly maturing to highly productive plankton communities (Pitcher \& Nelson 2006). During periodic relaxation and/or reversal of winds the nearshore flow is poleward, occasionally flushing the bays and transporting entrained organisms to the adjacent upwelling centers (Graham \& Largier 1997). Owing to this recirculation between upwelling centers and downstream bays, each of the headland-bay pairs is referred to as an upwelling cell (Shannon \& Nelson 1996).

In the present study, we assess whether the temporal and spatial variability in recruitment of intertidal invertebrates corresponds to seasonal and topographic patterns in coastal upwelling and contrasts in wave exposure. Based on a $5 \mathrm{yr}$ time series of monthly recruitment of intertidal mussels and barnacles at 8 sites spanning $400 \mathrm{~km}$ along the west coast of South Africa, we characterize patterns of recruitment variability across a range of spatial and temporal scales. We show that recruitment fluctuations can be related to spatial and temporal variability in upwelling intensity using a site-specific coastal upwelling index. Our results show strong spatio-temporal persistence of recruitment patterns, which has important implications for future initiatives of coastal management and conservation.

\section{MATERIALS AND METHODS}

Study region and sites. The southern Benguela upwelling region features a series of 3 upwelling cells (Fig. 1), each associated with a prominent headland upwelling center and a major downstream bay (Shannon \& Nelson 1996). The Hangklip cell east of the Cape of Good Hope experiences the least-developed upwelling plumes and features the largest, most en- 


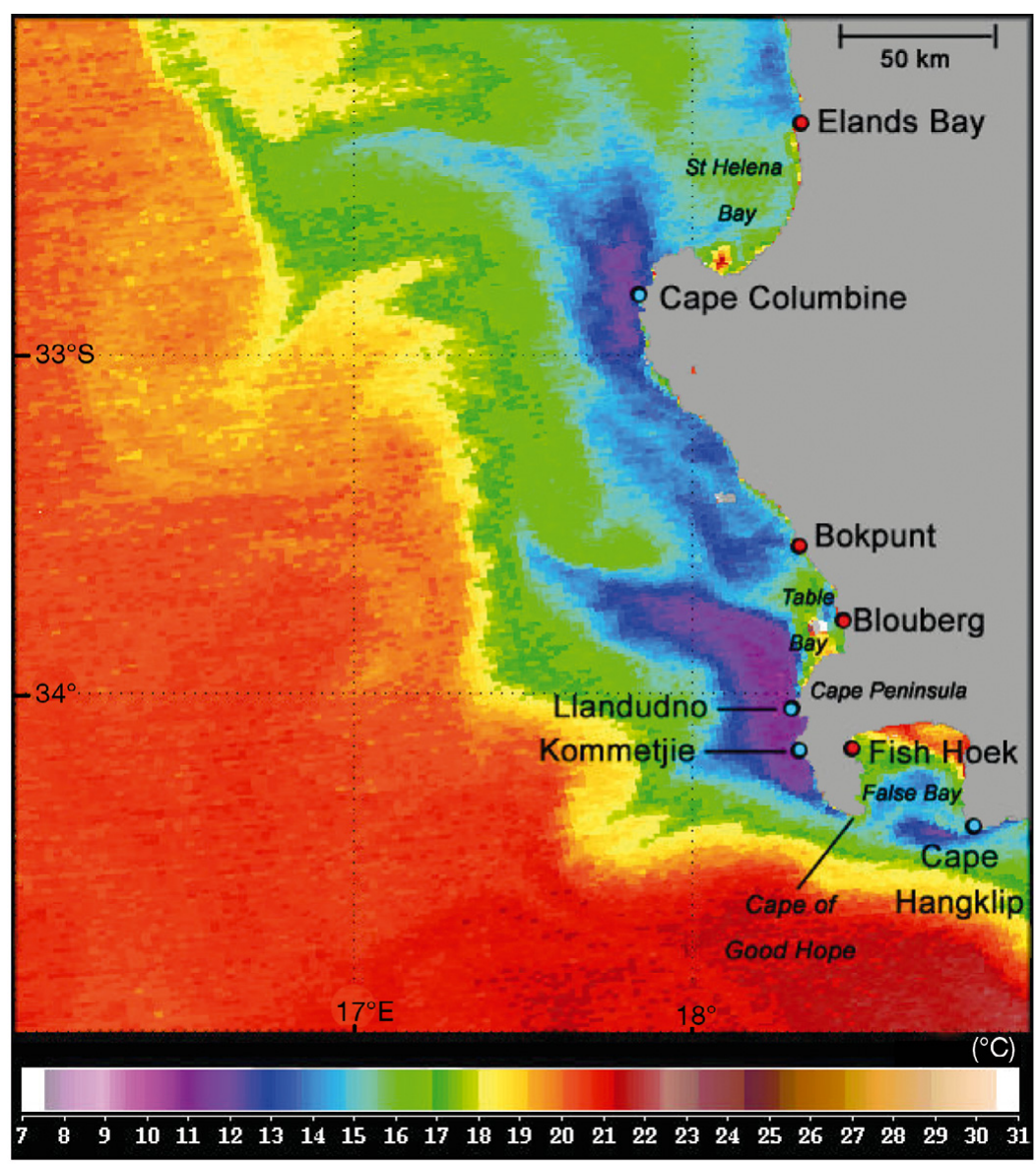

Fig. 1. MODIS satellite image of summer sea surface temperature on the west coast of South Africa showing cold water plumes associated with the headland upwelling centers at Cape Hangklip, Cape Peninsula and Cape Columbine, while warmer waters indicate weaker upwelling at the respective downstream bays (False Bay, Table Bay, St. Helena Bay). Sites where recruitment was monitored were chosen to span these topographically fixed discontinuities in upwelling (blue dots; upwelling centers; red dots: downstream bays). All sites, except Blouberg and Llandudno, consisted of a wave-exposed habitat and a wave-protected habitat

closed downstream bay (False Bay). The Cape Peninsula cell is associated with well-defined upwelling plumes, and a relatively small semi-enclosed bay (Table Bay), while the Cape Columbine cell experiences the most intense upwelling plumes in the southern Benguela region, and its sizable semi-enclosed bay (St Helena Bay) forms an important nursery area for numerous commercially exploited fish species (Hutchings 1992).

From 2002 to 2007, we monitored monthly recruitment of intertidal barnacles (over $64 \mathrm{mo}$ ) and mussels (over $61 \mathrm{mo}$ ) at 8 sites distributed across $\sim 400 \mathrm{~km}$ of the Atlantic coastline of South Africa (Fig. 1). For logistic reasons, sampling at the 2 easternmost sites (Cape Hangklip, Fish Hoek) was discontinued after 36 mo. Four sites were positioned at major headlands (up- welling centers) and 4 sites in downstream bays, and they were chosen to be as similar as possible with respect to bench width and inclination. Each site contained a wave-exposed and a waveprotected habitat, except for Blouberg and Llandudno, where the shoreline did not provide wave-protected conditions.

Sampling design. Recruitment of mussels and barnacles was estimated by employing standardized artificial substrata that mimic the structural complexity of natural filamentous matrices or rock surfaces onto which mussel and barnacle larvae, respectively, settle (e.g. Broitman et al. 2008). For mussels these comprised $\sim 55 \mathrm{~cm}^{3}$ mesh scouring pads, and for barnacles, $10 \times 10 \mathrm{~cm}$ plexiglass plates covered with SafetyWalk $^{\circledR}(3 \mathrm{M})$. At each habitat, 5 replicate collectors were positioned 5 to $15 \mathrm{~m}$ apart in the zones of highest abundance for each target taxon, i.e. in the midshore mussel bed and in the high-shore barnacle belt. Collectors were replaced monthly during spring tide and processed in the laboratory. All mussel recruits that settled in the pads were removed, collected in a $265 \mu \mathrm{m}$ sieve and counted with the aid of a dissecting microscope. Barnacle cyprids and metamorphs were counted directly on the plates under a dissecting microscope. Calcareous shell remains of dead barnacle recruits were included in these counts to minimize the potential effects of increased post-settlement mortality associated with artificial substrata. Recruitment rates are expressed as the number of recruits per collector per day in the field.

We were unable to distinguish between small recruits of the native species, Choromytilus meridionalis and Aulocamya ater, and the invasive Mytilus galloprovincialis (e.g. Bownes et al. 2008). These species were pooled and are henceforth referred to as 'mussels', but the samples were most probably dominated by $M$. galloprovincialis, which by far dominates the regional spawner biomass (>90\%, data not shown). Owing to the overall low numbers of barnacle recruits, we pooled recruits of the dominant invasive Balanus glandula ( $>80 \%$, data not shown) with the scarcer native Notomegabalanus algicola, Chthamalus dentatus, Tetraclita squamosa and Octomeris angulosa, subsequently referred to as 'barnacles'. All above species 
have planktotrophic larvae, with similar estimated larval durations of 10 to $40 \mathrm{~d}$ (Brown \& Roughgarden 1985, McQuaid \& Phillips 2000).

Data analyses. To avoid the potentially confounding effects of a biogeographic break at the Cape of Good Hope on seasonality of recruitment (Emanuel et al. 1992), all temporal analyses were based on the west coast sites only, although spatial analyses included all study sites.

Temporal recruitment patterns. To quantify seasonality, interannual variability and spatial synchrony of mussel and barnacle recruitment, we calculated average recruitment for each calendar month across sites and years, average (within-site) coefficients of variation (CVs) among years and CVs among sites. Time series data were linearly interpolated at monthly intervals to translate from the lunar cycle of collections (during spring tides) to the solar cycle (calendar months). To compare strengths of seasonality between the taxa in this study (and with other published work), we performed site-specific temporal autocorrelations (Spearman's rank), based on temporal rankings of monthly time series. We then averaged the resulting correlations at each lag investigated to provide a regional autocorrelation for each taxon. Strength of seasonality was evaluated with R-values $\left(\mathrm{R}_{\max }\right)$ at 12 mo lag. Missing data $(<5 \%)$ were substituted with long-term means for the corresponding site.

Spatial recruitment patterns. The present study captured variability in mean annual mussel and barnacle recruitment at 3 spatial scales corresponding to (1) large-scale differences among upwelling cells, (2) mesoscale differences in topography between upwelling centers and downstream bays and (3) smallscale differences in wave exposure. We used a 3-way nested ANOVA of mean annual recruitment rates with Cell (Cape Hangklip, Cape Peninsula, Cape Columbine), Topography (headland, bay) nested in Cell, and Exposure (wave exposed, wave protected), all considered fixed factors. We chose a nested design, since the levels of the nested factor (Topography) are different within each level of the main factor (Cell), i.e. headlands and bays were not identical among upwelling cells. Cell was considered fixed, since all cells in the region were sampled and no generality regarding cell differences will be inferred from results. Since barnacle recruitment was virtually non-existent at upwelling centers (see 'Results'), we fitted a 2-way full-factorial ANOVA with fixed factors Cell and Exposure to barnacle data from downstream bays only. Before analysis, we calculated mean annual recruitment rates from the monthly data for each collector position (i.e. 5 per wave-exposure habitat). To achieve a robust, balanced sampling design, we excluded sites that lacked a wave-protected habitat from this analysis. Data were log-transformed to attain normality and homogeneity of variances. Tukey's HSD tests were applied for posthoc comparisons.

To assess latitudinal trends, we used linear regression analysis between latitude and average monthly recruitment rates for wave-exposed sites. Recruitment data were log-transformed to meet model assumptions, which were assessed by visual inspection of the residuals.

Persistence of spatial recruitment patterns. To explore the persistence of the spatial recruitment patterns over time, rankings of sites in a given month were correlated with their rankings in all other months, and the Spearman's rank correlation coefficients $r_{S}$ averaged for pairs of months separated by given time lags (see Navarrete et al. 2008). This procedure was repeated for annual rankings.

Spatial and temporal relationships between upwelling and recruitment. A site-specific daily coastal upwelling index (UI) was defined as:

$$
\mathrm{UI}=\left(T_{\text {offshore }}-T_{\text {onshore }}\right) /\left(T_{\text {offshore }}-T_{\text {bottom }}\right)
$$

where $T_{\text {offshore }}$ represents temperatures offshore of the upwelling front and was calculated from moderate resolution imaging spectroradiometer (MODIS) sea surface temperature (SST) images as the average of a $30 \times$ $30 \mathrm{~km}$ square of pixels located $350 \mathrm{~km}$ offshore. The offshore pixels were chosen directly west of the Cape Columbine and Cape Peninsula upwelling cells and directly south of the Cape Hangklip cell. $T_{\text {onshore }}$ represents the temperature at 07:00 h measured in situ by temperature data loggers (model Tidbit, Onset) moored $1 \mathrm{~m}$ below low tide level at each wave-exposed site. This time of day was chosen because it was before the sun had begun to heat up the water and after the heat from the previous day's solar heating had dissipated. $T_{\text {bottom }}$ is a constant describing the temperature of the source water off the west coast of South Africa and was approximated as $8^{\circ} \mathrm{C}$. This index is similar to one described by Demarcq \& Faure (2000) except that $T_{\text {offshore }}$ represents the current situation offshore instead of the SST climatology, and $T_{\text {onshore }}$ represents the temperature in the surf zone instead of the minimum SST pixel value. It is therefore more suitable for describing inner-shelf conditions. We calculated the average UI $\left(\mathrm{UI}_{\mathrm{avg}}\right)$ and $\mathrm{SD}\left(\mathrm{UI}_{\mathrm{SD}}\right)$ for months corresponding to the recruitment time series. Potential noise in daily $T_{\text {offshore }}$ readings was smoothed with a $61 \mathrm{~d}$ running average. Monthly averages were based on a minimum of 10 daily UIs.

To investigate whether spatial recruitment patterns of mussels and barnacles reflect mesoscale patterns in upwelling intensity, we performed Pearson correlations between the long-term means of $\mathrm{UI}_{\mathrm{avg}}$ (from 
whole years of monthly averages for each site) and corresponding long-term means of recruitment. Since mussel recruitment showed a latitudinal trend (see 'Results'), we used residuals from a LOWESS regression of mean recruitment with latitude. Further, to assess whether temporal variability in recruitment at each site is linked to fluctuations in local upwelling, we used a generalized linear mixed model (GLMM) to test for the effects of $\mathrm{UI}_{\text {avg }}$ (random), Site (fixed), and their interaction on monthly recruitment rates. Restricted estimation of maximum likelihood (REML) was used to account for the crossed random factor and unbalanced design. Recruitment rates were logtransformed and analyses restricted to non-zero values to meet the assumptions of the model, and to eliminate cases where recruitment was zero because of factors other than upwelling (i.e. deficiency of larvae owing to absence of such factors as spawning and predation). To further describe the temporal relationship between monthly recruitment and upwelling intensity, as well as upwelling variability, we applied Pearson correlations between $\mathrm{UI}_{\mathrm{avg}}$ and $\mathrm{UI}_{\mathrm{SD}}$ for each site against corresponding recruitment rates (log-transformed for mussels).

\section{RESULTS}

\section{Temporal recruitment patterns}

Recruitment of both mussels and barnacles was strongly seasonal, and peaks occurred in austral summer (November to January) and spring (August to October), respectively. However, no month showed complete absence of recruitment (Fig. 2). Interannual variability within sites (CV among years) was moderate and fairly constant throughout the year. However, spatial variation (CV among sites) was substantial and varied among seasons for both taxa, particularly when recruitment maxima (mussels) and minima (barnacles) occurred.

Spatially averaged autocorrelations of recruitment time series from individual sites showed clear annual (12 mo) periodicity in both mussel and barnacle recruitment (Fig. 3). A 3 to 4 mo temporal decorrelation scale was similar for both taxa.

\section{Spatial recruitment patterns}

Across the $400 \mathrm{~km}$ of coastline, mean annual recruitment of mussels showed a strong relationship with latitude, increasing exponentially northwards (regression: $\left.R^{2}=0.87, p<0.001\right)$, whereas recruitment of barnacles showed no such trend $\left(R^{2}=0.01, p=0.79\right)$ but was significantly greater in the southernmost bay.

For mussels, ANOVA revealed differences in mean annual recruitment at all spatial scales investigated, although the effects were dampened by significant interactions (Table 1, Fig. 4A). In both wave-exposed and wave-protected habitats, mussel recruitment was an order of magnitude higher in the northern (Cape Columbine) upwelling cell, than in the 2 southern cells. The strikingly consistent mesoscale structure of
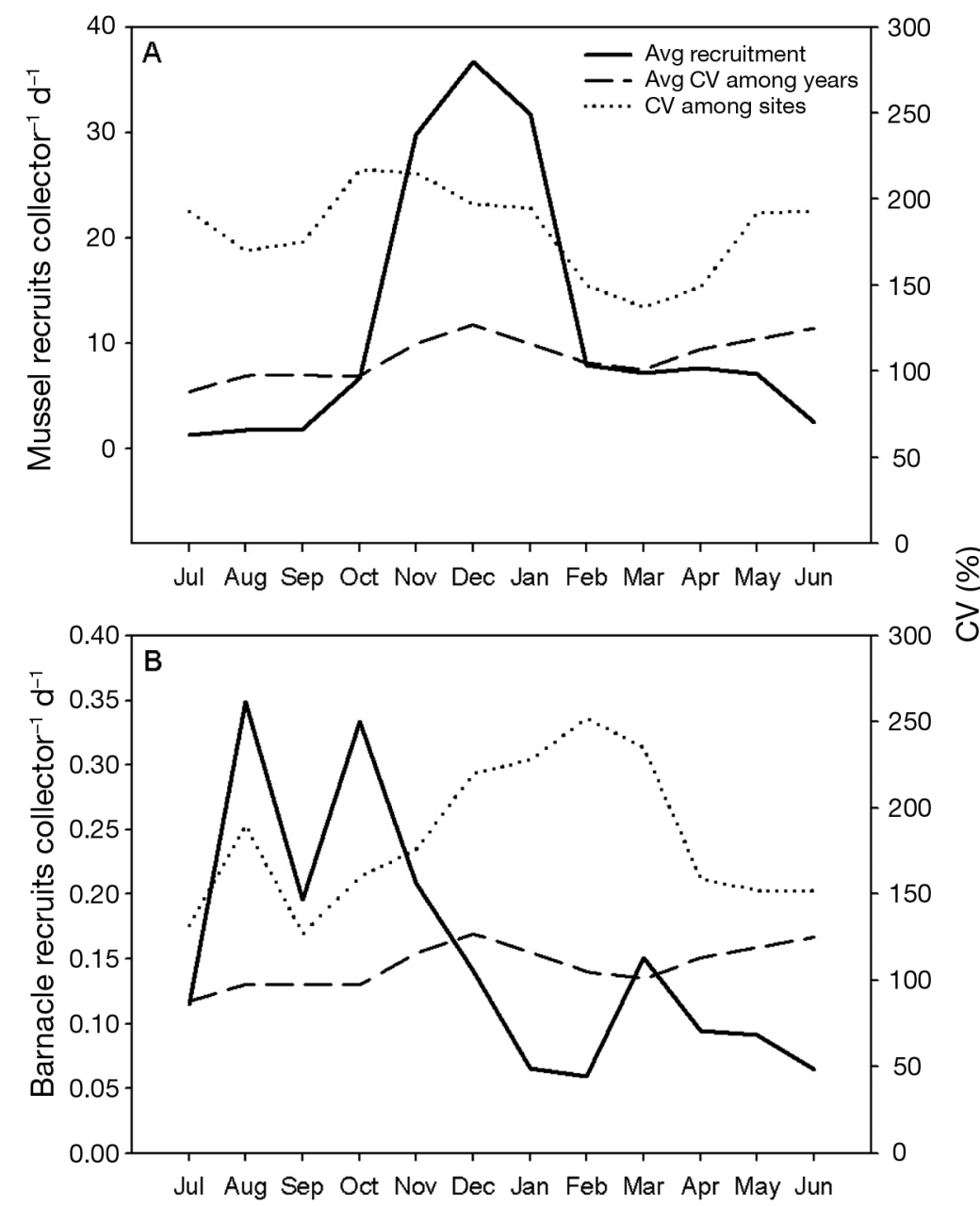

Fig. 2. Temporal patterns of (A) mussel and (B) barnacle recruitment. Peaks in average recruitment per calendar month indicate seasonality. Interannual variability and spatial synchrony of the seasonal pattern are illustrated, respectively, by the coefficients of variation (CV) among years (within site averages) and among sites. Note the 100 -fold difference in scales, reflecting much higher recruitment rates of mussels than barnacles. Data are standardized per day per settlement collector 


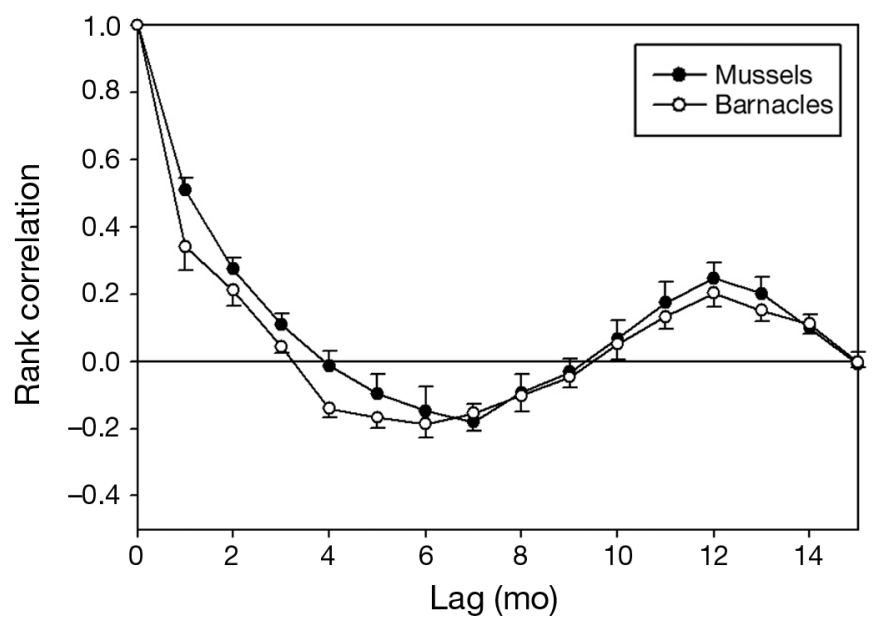

Fig. 3. Temporal rank-based autocorrelation of monthly recruitment rates for mussels and barnacles. Since time series were averaged among sites error bars $( \pm \mathrm{SE})$ indicate spatial variation. The strength of the seasonal signal in recruitment was very similar for mussels and barnacles as indicated by similar correlation maxima $\left(\mathrm{R}_{\max }\right)$ at an annual frequency

Table 1. ANOVA of mean annual recruitment rates of mussels and barnacles, capturing variability on 3 spatial scales: among upwelling cells (Cell), between major headlands and downstream bays (Topography, nested within Cell), and between wave-exposed and wave-protected habitats (Exposure). The effect of Topography was omitted from analysis for barnacles owing to near absence of recruitment at headlands (see Fig. 4B)

\begin{tabular}{|lrrrr|}
\hline Source & df & MS & \multicolumn{1}{c|}{$F$} & $\mathrm{p}$ \\
\hline Mussels & & & & \\
Cell & 2 & 71.75 & 452.90 & $<0.0001$ \\
Topography (Cell) & 3 & 13.79 & 87.07 & $<0.0001$ \\
Exposure & 1 & 1.73 & 10.95 & 0.0011 \\
Cell $\times$ Exposure & 2 & 1.67 & 10.55 & $<0.0001$ \\
Topography (Cell) $\times$ & 3 & 1.12 & 7.05 & 0.0001 \\
$\quad$ Exposure & & & & \\
Error & 258 & 0.16 & & \\
Barnacles & & & & \\
Cell & 2 & 4.36 & 28.51 & $<0.0001$ \\
Exposure & 1 & 0.08 & 0.50 & 0.4798 \\
Cell $\times$ Exposure & 2 & 0.49 & 3.16 & 0.0457 \\
Error & 124 & 0.15 & & \\
\hline
\end{tabular}

recruitment rates, which were lower at headlands than in bays, was less pronounced in the Cape Columbine cell, which may be an artifact of the disproportional effect that log-transformation had on the larger numbers in this cell. Recruitment rates were consistently higher in wave-exposed habitats than in protected habitats, although the strength of this effect varied among headlands and downstream bays (significant Topography [Cell] $\times$ Exposure interaction).
Barnacle recruitment (Table 1, Fig. 4B) was virtually absent at headlands and thus analyses were restricted to downstream bays. Recruitment rates varied significantly among upwelling cells, with highest recruitment rates occurring in the easternmost (Cape Hangklip) cell. While recruitment was consistently higher in wave-exposed habitats than in wave-protected habitats, the effect varied among cells (significant Cell $\times$ Exposure interaction) and appeared weakest at the Cape Hangklip cell.

\section{Persistence of the spatial recruitment patterns}

The ranking of sites according to their recruitment rates was highly persistent over time for mussels, but much less so and more variable for barnacles (Fig. 5A). Periodic oscillations in correlation at annual frequencies were evident for both species but were more pronounced for barnacles. Equivalent analyses correlating spatial ranks of recruitment rates among years showed that both mussels and barnacles displayed highly persistent spatial rankings in recruitment on an annual scale (Fig. 5B). Trends of the correlations of annual site rankings over increasing annual time lags were opposite for mussels and barnacles: mussel recruitment was more persistent between consecutive years and decreased with greater lags, while barnacle recruitment was less correlated between adjacent years than between longer time intervals.

\section{Spatial and temporal relationships between upwelling intensity and recruitment}

As expected, each headland was characterized by a higher long-term $\mathrm{UI}_{\mathrm{avg}}$ than that found at its corresponding downstream bay (Table 2). No clear latitudinal trend in upwelling intensity was evident (Pearson correlation: $r=0.45, p=0.273$ ). Long-term means of the spatial patterns of mussel recruitment were not correlated with along-shore differences in upwelling intensity $(r=0.35, p=0.494)$, even after removal of the regional trend in mussel recruitment $(r=0.26, p=$ 0.520). In contrast, barnacle recruitment was significantly negatively correlated with upwelling intensity among sites $(\mathrm{r}=-0.87, \mathrm{p}=0.021)$.

The GLMM used for resolving the temporal relationship between upwelling and recruitment explained substantially higher variance for mussels $\left(\mathrm{R}^{2}=\right.$ $0.56)$ than for barnacles $\left(R^{2}=0.24\right)$. For both taxa, the effect of upwelling variability on monthly recruitment rates varied among sites (significant interaction; Table 3). Fluctuations in upwelling intensity played a 

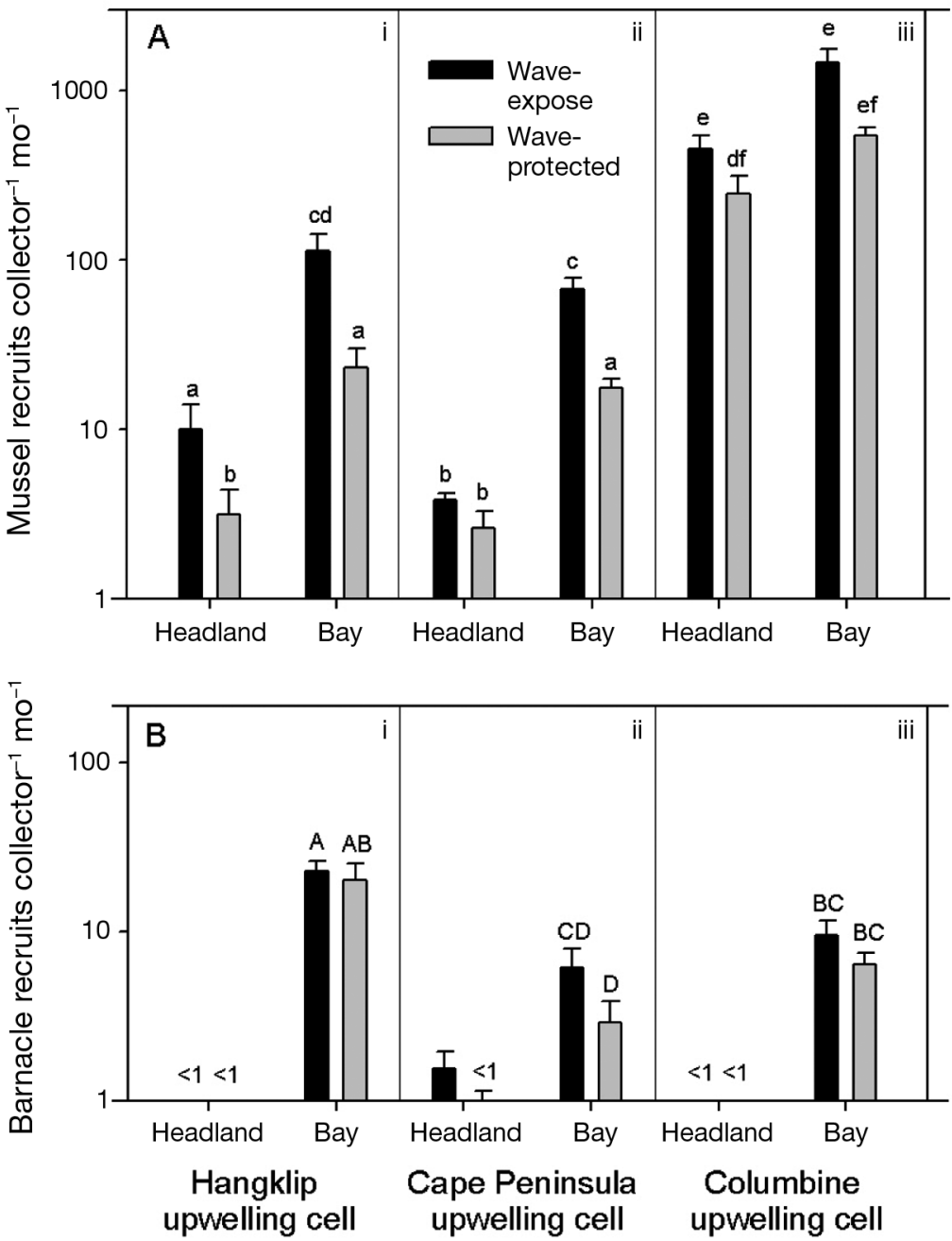

Fig. 4. Spatial patterns of (A) mussel and (B) barnacle recruitment (mean + SE) capturing variability at 3 hierarchical spatial scales (large, meso- and small scale) (i) among upwelling cells (arranged from southeast to northwest), (ii) between headlands forming upwelling centers and downstream bays and (iii) between wave-exposed and wave-protected habitats at a site. Levels not sharing common letters above the bars are significantly different (Tukey's HSD test, $\mathrm{p}<0.05$ ). Note the logarithmic scale on the $y$-axes emphasizing the near absence of barnacle recruitment at headlands

\section{DISCUSSION}

Along the $400 \mathrm{~km}$ stretch of coastline examined around the southwestern tip of South Africa, spatial and temporal recruitment patterns differed between mussels and barnacles in various aspects. (1) Peak recruitment occurred in austral summer months for mussels, while barnacle recruitment peaked in spring. (2) While mussel recruitment decreased exponentially with latitude, barnacle recruitment was greatest in the southernmost bay. (3) Across small spatial scales $(<1 \mathrm{~km})$, wave exposure enhanced the recruitment of mussels and, to a lesser extent, barnacles. (4) The spatial ranking of recruitment among months was remarkably persistent for mussels, but less so for barnacles. (5) Time-integrated spatial patterns in barnacle recruitment rates were inversely related to spatial variability in upwelling intensity, whereas no such relationship existed for mussels. (6) Month-to-month variability in mussel recruitment was positively correlated with temporal fluctuations in upwelling intensity at most sites, while barnacle recruitment corresponded only rarely with monthly derived UIs.

Conversely, mussels and barnacles shared several similarities: (1) strongly seasonal recruitment peaks that persisted for 3 to $4 \mathrm{mo}$, (2) significantly less recruitment at upwelling center headlands than at downstream bays and (3) spatial patterns in recruitment that were persistent across years. Below, we discuss potential processes underlying these patterns. more important role in determining recruitment dynamics for mussels than for barnacles (see variance components, Table 3). Correlations of $\mathrm{UI}_{\mathrm{avg}}$ and $\mathrm{UI}_{\mathrm{SD}}$ for each site with corresponding monthly recruitment rates showed that mussel recruitment was consistently positively related to upwelling intensity $\left(\mathrm{UI}_{\mathrm{avg}}\right)$ and/or its variability $\left(\mathrm{UI}_{\mathrm{SD}}\right)$ in all but the 2 southernmost sites (Fig. 6A). In contrast, barnacle recruitment was negatively correlated with upwelling intensity and variability at 2 central sites, and positively correlated with upwelling variability at the northernmost site (Fig. 6B).

\section{Temporal recruitment patterns and their link to upwelling dynamics}

Recruitment of mussels and barnacles was strongly seasonal with relatively low interannual variability. Mussel recruitment peaked during austral summer, which coincides with seasonal equatorward wind events that drive intermittent coastal upwelling alternating with relaxation and occasional downwelling events. In contrast, peak barnacle recruitment occurred in spring during the transition from predominant poleward (downwelling-inducing) to equa- 
torward winds. Seasonality of recruitment can be a consequence of seasonal processes, such as reproduction, seasonal differences in mortality rates of larvae or settlers and/or seasonality in coastal circulation patterns providing food and transport for larvae. Repro-

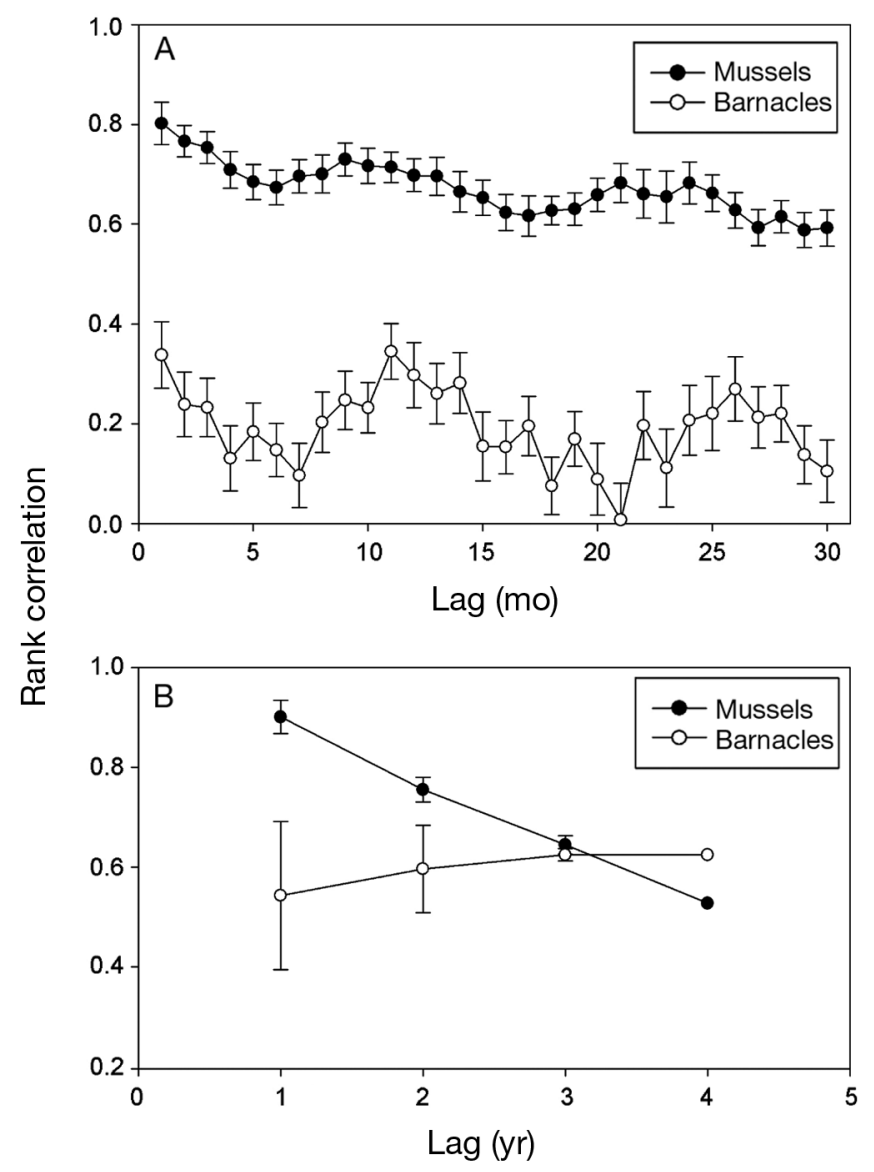

Fig. 5. Persistence of the spatial recruitment patterns (rankings of sites) of mussels and barnacles (A) over months and (B) over years. Coefficients of correlations of pairs of months (rankings) separated by an equal time interval (lag) were averaged and error bars $( \pm \mathrm{SE})$ indicate the variability among them

Table 2. Long-term means and SEs of upwelling indices (UI) for sites listed from north to south, specifying their positions, associations with the 3 upwelling cells and topography. UW: upwelling center; DS: downstream bay

\begin{tabular}{|lccccccc|}
\hline Site & $\begin{array}{c}\text { Latitude } \\
\left({ }^{\circ} \mathrm{S}\right)\end{array}$ & $\begin{array}{c}\text { Longitude } \\
\left({ }^{\circ} \mathrm{E}\right)\end{array}$ & $\begin{array}{c}\text { Upwelling } \\
\text { cell }\end{array}$ & Topography & UI & SE \\
\hline Elands Bay & 32.31 & 18.32 & Cape Columbine & DS & 0.55 & 0.02 \\
Cape Columbine & 32.82 & 17.84 & Cape Columbine & UW & 0.64 & 0.02 \\
Bokpunt & 33.56 & 18.30 & Cape Peninsula & DS & 0.50 & 0.02 \\
Blouberg & 33.80 & 18.46 & Cape Peninsula & DS & 0.45 & 0.02 \\
Llandudno & 34.01 & 18.33 & Cape Peninsula & UW & 0.55 & 0.03 \\
Kommetjie & 34.15 & 18.35 & Cape Peninsula & UW & 0.52 & 0.03 \\
Fish Hoek & 34.13 & 18.45 & Cape Hangklip & DS & 0.23 & 0.02 \\
Cape Hangklip & 34.38 & 18.84 & Cape Hangklip & UW & 0.53 & 0.03 \\
\hline
\end{tabular}

ductive output of the mussels investigated in the present study occurs in 2 to 3 pulses in different seasons (van Erkom Schurink \& Griffiths 1991), and the same is true for the spatially dominant invasive barnacle Balanus glandula in its native environment (Barnes \& Barnes 1956). In this context, our results suggest that physical transport processes, larval mortality or both may play an important role in the seasonality of recruitment rates. Although the temporal resolution of monthly sampling in this study was too coarse to detect specific larval transport mechanisms, the strong and consistent positive relationship we found between temporal variability in upwelling intensity and monthly mussel recruitment rates implies that nearshore oceanographic processes are important in the recruitment process.

The typical duration of recruitment peaks (or troughs), expressed by temporal decorrelation scales of 3 to 4 mo (i.e. the initial time lag at which the temporal autocorrelation approaches zero), were remarkably similar between mussels and barnacles in our study, as well as in studies in other upwelling regions (Navarrete et al. 2008). Based on our monthly sampling intervals, this indicates that the recruitment pulses typically occur in consecutive months of the same season, possibly reflecting the seasonal nature of oceanic variability.

\section{Spatial recruitment patterns and relationship with upwelling intensity}

Along the $400 \mathrm{~km}$ stretch of coastline examined, mussel and barnacle recruitment showed contrasting large-scale trends. Mussel recruitment increased exponentially towards the north, supporting previous findings (Harris et al. 1998, Xavier et al. 2007). The steep decline in recruitment south of Cape Columbine may reflect a regional shift in nearshore oceanographic conditions from intermittent upwelling in the south to more persistent upwelling in the north (Wieters et al. 2009), which may act as a transport barrier for pelagic larvae. Interestingly, the direction of this regional trend is opposite to similar transitions in other eastern boundary upwelling regions, where higher recruitment rates of mussels and barnacles were associated with less persistent upwelling and lower recruitment associated with more upwelling (Connolly et al. 2001, Navarrete et al. 2005, Broitman et al. 2008). Indirect evidence from the spread of the now spatially dominant, invasive mussel Mytilus galloprovincialis, which was introduced at 
Table 3. Relationship between the temporal variability of upwelling and recruitment of mussels and barnacles at all 8 sites sampled, based on a general linear mixed model (using restricted estimation of maximum likelihood, REML), with factors Upwelling (random) and Site (fixed) and their interactions. Owing to absence of barnacle recruitment at Cape Hangklip this site was excluded from the barnacle model. *With REML, SS for testing random effects are shrunk and $F$ is not calculated; instead the variance component and its $95 \%$ confidence limits (CLs) are presented

\begin{tabular}{|c|c|c|c|c|c|c|c|c|}
\hline \multirow[t]{2}{*}{ Source } & \multirow[t]{2}{*}{ df } & \multicolumn{3}{|c|}{-Fixed - } & \multirow[b]{2}{*}{$\begin{array}{c}\text { Variance } \\
\text { component }\end{array}$} & \multirow{2}{*}{$\begin{array}{c}\text { Ran } \\
95 \% \\
\text { lower CL }\end{array}$} & \multirow{2}{*}{$\begin{array}{l}95 \% \\
\text { upper CL }\end{array}$} & \multirow[b]{2}{*}{$\begin{array}{l}\% \text { of total } \\
\text { variance }\end{array}$} \\
\hline & & SS & $F$ & $\mathrm{p}$ & & & & \\
\hline \multicolumn{9}{|l|}{ Mussels } \\
\hline Upwelling & 1,278 & 1.05 & $*$ & * & 0.30 & 0.04 & 469784.33 & 39.41 \\
\hline Site & 7,278 & 107.57 & 33.46 & $<0.0001$ & & & & \\
\hline Upwelling $\times$ Site & 7,278 & 16.02 & 4.98 & $<0.0001$ & & & & \\
\hline Residual & 278 & 292.97 & & & 0.46 & & & 60.59 \\
\hline \multicolumn{9}{|l|}{ Barnacles } \\
\hline Upwelling & 1,164 & 0.15 & * & * & 0.07 & 0.006 & $6.02 \times 10^{42}$ & 13.81 \\
\hline Site & 6,164 & 8.98 & 3.67 & 0.0019 & & & & \\
\hline Upwelling $\times$ Site & 6,164 & 9.40 & 3.84 & 0.0013 & & & & \\
\hline Residual & 164 & 66.94 & & & 0.41 & & & 86.19 \\
\hline
\end{tabular}

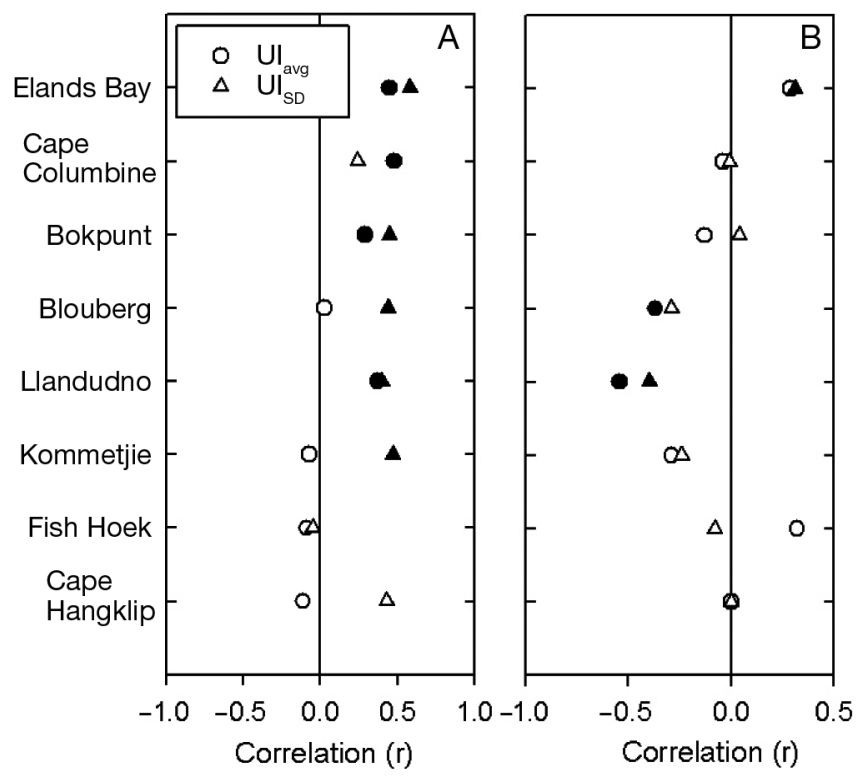

Fig. 6. Spatial relationship between upwelling and recruitment of (A) mussels and (B) barnacles. Sites are arranged from north (top) to south (bottom) and only include exposed habitats (where temperature loggers were installed). Correlations of a monthly averaged site-specific upwelling index $\left(\mathrm{UI}_{\mathrm{avg}}\right)$ and associated standard deviation $\left(\mathrm{UI}_{\mathrm{SD}}\right)$ with recruitment in the corresponding month are indicated. Significant results (sequential Bonferroni) are shown as black symbols

a point source just south of Cape Columbine in the 1970s and has expanded its range much faster northward than southward (Branch \& Steffani 2004), suggests that the steep gradient in mussel recruitment may be associated with its point of introduction. If the faster northward expansion of this non-native mussel was a result of predominantly northward larval dispersal, low recruitment rates in the south may reflect the unique topography of the African continent, which ends at ca. $34.5^{\circ} \mathrm{S}$ latitude, thus lacking upstream habitats to host spawning stocks as sources for mussel recruitment. Barnacle recruitment showed no clear-cut latitudinal trend but was greater at the southeastern extreme than elsewhere. This may be a biogeographic effect, as barnacles become abruptly less abundant west than east of the Cape of Good Hope (M. C. Pfaff pers. obs.).

Probably the most striking finding of this study was the clear signature of mesoscale topographical features in spatial recruitment patterns of both mussels and barnacles. Protruding headlands experienced little mussel and virtually no barnacle recruitment, while downstream bays received significantly higher numbers of recruits. Similar topographically modulated recruitment patterns have been recorded for crabs and sea urchins found in the California Current (Ebert \& Russell 1988, Botsford 2001), and for crabs in the Humboldt Current (Palma et al. 2006), though only marginally for mussels and barnacles in the Humboldt Current (Navarrete et al. 2005). The mechanism by which headland-bay topography controls recruitment is likely to be linked to larval transport processes. Upwelling intensity in the southern Benguela is spatially variable, and upwelling centers are locked to prominent headlands (Shannon \& Nelson 1996, Pitcher \& Nelson 2006). Our UI correctly identified intense upwelling at headlands rather than in corresponding downstream bays. While upwelling and relaxationdownwelling may equally provide onshore transport mechanisms for larvae (Farrell et al. 1991, Wing et al. 1995b, Shanks et al. 2000, Garland et al. 2002), a fundamental prerequisite is the availability of larvae in the transported water mass. Extensive research on the hydrography of the Cape Columbine upwelling cell 
has shown that during upwelling an equatorward coastal jet current is formed off the headland, but wind-stress shear favors clockwise circulation within the associated downstream bay, promoting retentive circulation patterns (Penven et al. 2000, Pitcher \& Nelson 2006). Many bays are associated with such recirculation patterns (Okubo 1973), where the entrapment of water, suspended matter and larvae leads to prolonged residence times, warmer waters and higher primary productivity, all of which may aid the nourishment, rapid development and concentration of competent (i.e. ready to settle) larvae (Archambault et al. 1998). In contrast, the upwelling plumes associated with headlands carry water of deep origin, which has limited contact with the nearshore and may thus lack settlers from coastal habitats. However, larvae may be able to counteract their offshore transport through behavioral mechanisms, such as active positioning low in the water column, as has recently been demonstrated for the vigorous upwelling regions of northern California (Morgan et al. 2009) and Oregon (Shanks \& Shearman 2009), USA. Similarly, the offshore larval pool may be spatially homogeneous, and variability in onshore recruitment is primarily the result of local-scale processes (Rilov et al. 2008). Therefore, further studies sampling larval distributions are needed to resolve the effect of topography on spatio-temporal variability of larval availability and its link to recruitment on the shore.

At spatial scales of $<1 \mathrm{~km}$, we observed consistently higher recruitment rates of mussels (and to a lesser extent also barnacles) in wave-exposed than in protected habitats, which appears to be a general pattern in the southern Benguela upwelling region (Branch \& Steffani 2004). Proposed mechanisms for such patterns include an elevated larval supply rate linked to greater water flux (Bustamante \& Branch 1996) and the possibility that wind-generated fronts act as barriers for larval delivery into small waveprotected bays (McCulloch \& Shanks 2003). Alternatively, post-settlement mortality rates may be lower on exposed shores, where splashing waves may reduce desiccation, food shortage or predation. Regardless of the mechanism, differences in recruitment rates of these dominant benthic filter-feeders can strongly influence species interactions and community regulation (Connell 1985, Gaines \& Roughgarden 1985, Roughgarden et al. 1988, Menge et al. 1997, Navarrete et al. 2005) and thus contribute to the striking differences in intertidal community structure observed between wave-exposed and wave-protected habitats along the South African coast (Emanuel et al. 1992, Bustamante \& Branch 1996).

The spatial patterns of recruitment identified in the present study were remarkably persistent over time.
Throughout the year and with little interannual variability, mussel recruitment, while strongly seasonal, appeared to maintain latitudinal trends, topographically modulated mesoscale patterns and small-scale contrasts between wave-exposed and wave-protected habitats. Although barnacle recruitment had less predictable spatial structure throughout the year, the clear mesoscale contrast between headlands and bays was persistent among years. Similar regularities exist for a number of intertidal mussel and barnacle species of the Humboldt and California upwelling systems (Navarrete et al. 2008), which suggest that common factors determine recruitment, most probably associated with topographically locked circulation patterns.

\section{CONCLUSIONS}

The present study confirms that a clear link exists between spatio-temporal variability in nearshore hydrographic conditions recruitment dynamics of 2 of the most important space-occupying intertidal invertebrate taxa in the southern Benguela upwelling region, mussels and barnacles. We demonstrated not only that spatial recruitment patterns mirror mesoscale differences in topographically modulated upwelling and small-scale gradients of wave action, but also that these patterns are remarkably coherent between unrelated taxa and persistent over time. Achieving such predictability is of particular relevance for the future management and conservation of coastal ecosystems.

Acknowledgements. Many people helped collect and process data for this study. Special thanks to C. Ruiz, C. Holness, M. de Ponte Machado, J. Reed, A. Azieb, C. Louw, L. Kemp, V. Hoffmann, E. Brown, M. Smith, K. Reaugh Flower, D. Campregher and $\mathrm{C}$. Whittle for their commitment and time. A. Ellis, C. Attwood, J. Largier, S. Navarrete, F. Shillington and C. Griffiths offered generous advice about data analyses and interpretation. This study was funded by National Research Foundation (NRF) and Andrew Mellon Foundation grants to G.M.B. M.C.P received additional funding from the University of Cape Town. E.A.W. acknowledges additional support from a Rhodes University Fellowship.

\section{LITERATURE CITED}

Archambault P, Roff J, Bourget E, Bang B, Ingram G (1998) Nearshore abundance of zooplankton in relation to shoreline configuration and mechanisms involved. J Plankton Res 20:671-690

Barnes H, Barnes M (1956) The general biology of Balanus glandula Darwin. Pac Sci 10:415-422

> Botsford L (2001) Physical influences on recruitment to California Current invertebrate populations on multiple scales. ICES J Mar Sci 58:1081-1091

Bownes S, Barker N, McQuaid C (2008) Morphological 
identification of primary settlers and post-larvae of three mussel species from the coast of South Africa. Afr J Mar Sci 30:233-240

> Branch G, Steffani C (2004) Can we predict the effect of alien species? A case-history of the invasion of South Africa by Mytilus galloprovincialis (Lamarck). J Exp Mar Biol Ecol 300:189-215

Broitman BR, Blanchette CA, Gaines SD (2005) Recruitment of intertidal invertebrates and oceanographic variability at Santa Cruz Island, California. Limnol Oceanogr 50: 1473-1479

Broitman BR, Blanchette CA, Menge BA, Lubchenco J and others (2008) Spatial and temporal patterns of invertebrate recruitment along the West Coast of the United States. Ecol Monogr 78:403-421

Brown S, Roughgarden J (1985) Growth, morphology, and laboratory culture of larvae of Balanus glandula (Cirripedia, Thoracica). J Crustac Biol 5:574-590

Bustamante R, Branch G (1996) Large scale patterns and trophic structure of Southern African rocky shores: the roles of geographic variation and wave exposure. J Biogeogr 23:339-351

> Connell J (1985) The consequences of variation in initial settlement vs. post-settlement mortality in rocky intertidal communities. J Exp Mar Biol Ecol 93:11-45

Connolly SR, Menge BA, Roughgarden JE (2001) A latitudinal gradient in recruitment of intertidal invertebrates in the Northeast Pacific Ocean. Ecology 82:1799-1813

> Demarcq H, Faure V (2000) Coastal upwelling and associated retention indices derived from satellite SST. Application to Octopus vulgaris recruitment. Oceanol Acta 23:391-408

Ebert TA, Russell MP (1988) Latitudinal variation in size structure of the west coast purple sea urchin: a correlation with headlands. Limnol Oceanogr 33:286-294

Emanuel B, Bustamante R, Branch G, Eekhout S, Odendaal F (1992) A zoogeographic and functional approach to the selection of marine reserves on the west coast of South Africa. S Afr J Mar Sci 12:341-354

> Farrell T, Bracher D, Roughgarden J (1991) Cross-shelf transport causes recruitment to intertidal populations in Central California. Limnol Oceanogr 36:279-288

Gaines S, Roughgarden J (1985) Larval settlement rate: a leading determinant of structure in an ecological community of the marine intertidal zone. Proc Natl Acad Sci USA 82:3707-3711

> Gan J, Allen J (2002) A modeling study of shelf circulation off northern California in the region of the Coastal Ocean Dynamics Experiment. Simulations and comparisons with observations. J Geophys Res 107:3184

Garland E, Zimmer C, Lentz S (2002) Larval distributions in inner shelf waters: the roles of wind-driven cross-shelf currents and diel vertical migrations. Limnol Oceanogr 47:803-817

Graham WM, Largier JL (1997) Upwelling shadows as nearshore retention sites: the example of northern Monterey Bay. Cont Shelf Res 17:509-532

Harris J, Branch G, Elliott B, Currie B and others (1998) Spatial and temporal variability in recruitment of intertidal mussels around the coast of southern Africa. S Afr J Zool 33:1-11

> Hunt HL, Scheibling RE (1996) Physical and biological factors influencing mussel (Mytilus trossulus, M. edulis) settlement on a wave-exposed rocky shore. Mar Ecol Prog Ser 142:135-145

Hutchings L (1992) Fish harvesting in a variable, productive environment - searching for rules or searching for exceptions? S Afr J Mar Sci 12:297-318
Jury M (1988) Case studies of the response and spatial distribution of wind-driven upwelling off the coast of Africa: 29-34 south. Cont Shelf Res 8:1257-1271

> Lagos NA, Castilla JC, Broitman BR (2008) Spatial environmental correlates of intertidal recruitment: a test using barnacles in northern Chile. Ecol Monogr 78:245-261

> McCulloch A, Shanks A (2003) Topographically generated fronts, very nearshore oceanography and the distribution and settlement of mussel larvae and barnacle cyprids. J Plankton Res 25:1427-1439

> McQuaid C, Phillips T (2000) Limited wind-driven dispersal of intertidal mussel larvae: in situ evidence from the plankton and the spread of the invasive species Mytilus galloprovincialis in South Africa. Mar Ecol Prog Ser 201: 211-220

> Menge BA, Sutherland JP (1987) Community regulation: variation in disturbance, competition, and predation in relation to environmental stress and recruitment. Am Nat 130:730-757

> Menge BA, Daley BA, Wheeler PA, Dahlhoff E, Sanford E, Strub PT (1997) Benthic-pelagic links and rocky intertidal communities: bottom-up effects on top-down control? Proc Natl Acad Sci USA 94:14530-14535

Menge B, Daley B, Lubchenco J, Sanford E and others (1999) Top-down and bottom-up regulation of New Zealand rocky intertidal communities. Ecol Monogr 69:297-330

> Morgan SG, Fisher JL, Miller SH, McAfee ST, Largier JL (2009) Nearshore larval retention in a region of strong upwelling and recruitment limitation. Ecology 90: 3489-3502

- Navarrete SA, Wieters EA, Broitman BR, Castilla JC (2005) Scales of benthic-pelagic coupling and the intensity of species interactions: from recruitment limitation to topdown control. Proc Natl Acad Sci USA 102:18046-18051

Navarrete SA, Broitman BR, Menge BA (2008) Interhemispheric comparison of recruitment to intertidal communities: pattern persistence and scales of variation. Ecology 89:1308-1322

- Okubo A (1973) Effect of shoreline irregularities on streamwise dispersion in estuaries and other embayments. Neth J Sea Res 6:213-224

Palma AT, Pardo LM, Veas R, Cartes C and others (2006) Coastal brachyuran decapods: settlement and recruitment under contrasting coastal geometry conditions. Mar Ecol Prog Ser 316:139-153

Penven P, Roy C, Colin de Verdiere A, Largier J (2000) Simulation of a coastal jet retention process using a barotropic model. Oceanol Acta 23:615-634

Pitcher G, Nelson G (2006) Characteristics of the surface boundary layer important to the development of red tide in the southern Namaqua shelf of the Benguela upwelling system. Limnol Oceanogr 51:2660-2674

> Rilov G, Dudas S, Menge B, Grantham B, Lubchenco J, Schiel D (2008) The surf zone: a semi-permeable barrier to onshore recruitment of invertebrate larvae? J Exp Mar Biol Ecol 361:59-74

Roughgarden J, Gaines S, Possingham H (1988) Recruitment dynamics in complex life cycles. Science 241:1460-1466

- Shanks A, Shearman R (2009) Paradigm lost? Cross-shelf distributions of intertidal invertebrate larvae are unaffected by upwelling or downwelling. Mar Ecol Prog Ser 385:189-204

Shanks A, Largier J, Brink L, Brubaker J, Hooff R (2000) Demonstration of the onshore transport of larval invertebrates by the shoreward movement of an upwelling front. Limnol Oceanogr 45:230-236

Shannon L, Nelson G (1996) The Benguela: large scale fea- 
tures and processes and system variability. In: Wefer G, Berger W, Siedler G, Webb D (eds) The South Atlantic: present and past circulation. Springer, Berlin, p 163-210

van Erkom Schurink C, Griffiths C (1991) A comparison of reproductive cycles and reproductive output in four southern African mussel species. Mar Ecol Prog Ser 76: 123-134

Wieters E, Broitman B, Branch G (2009) Benthic community structure and spatio-temporal thermal regimes in two upwelling ecosystems: comparisons between South Africa and Chile. Limnol Oceanogr 54:1060-1072

Editorial responsibility: Steven Morgan,

Bodega Bay, California, USA
Wing S, Botsford L, Largier J, Morgan L (1995a) Spatial structure of relaxation events and crab settlement in the northern California upwelling system. Mar Ecol Prog Ser 128: $199-211$

Wing S, Largier J, Botsford L, Quinn J (1995b) Settlement and transport of benthic invertebrates in an intermittent upwelling region. Limnol Oceanogr 40:316-329

Xavier B, Branch G, Wieters E (2007) Abundance, growth and recruitment of Mytilus galloprovincialis on the west coast of South Africa in relation to upwelling. Mar Ecol Prog Ser 346:189-201

Submitted: October 19, 2010; Accepted: December 17, 2010 Proofs received from author(s): February 23, 2011 